\title{
A Reformulation of the Dual Career Conceptual Model for Analysis in an Organizational Scope: Revealing new Aspects
}

\author{
Heliani Berlato ${ }^{\dagger}$ \\ Universidade de São Paulo \\ Karen Florencio Corrêa ${ }^{\Omega}$ \\ Universidade de São Paulo
}

\begin{abstract}
Couples who live a dual career, in general, are characterized by their continuing professional engagement and their desire for personal growth together. It is a synergy between career aspirations and family sphere, so that they co-exist; reflecting nowadays, a challenge for people who seek to live this duality. Not exempt from it, it is possible to understand the need for management models of people who are in harmony with the desires of dual career couples who are part of organizations. If in the 1980s the existence of dual career couples was not so common in Brazil, nowadays organizations increasingly receive these couples, which impacts the need for people management models to keep up with these social changes. Therefore, the model recognizes that the personal dimension (impacts) on the organizational context cannot be avoided, and also that other factors affect both spheres (personal and organizational) when referring to the normative roles that permeate these areas. The main intention of this essay is to construct a theoretical model of dual career to consider the factor - organization, as vital to understand (and accept) the need to consider other dimensions on the dual career analytical perspective. The first evidences of dual career studies in Brazil revealed that the look at this movement only from the individual's margin is limited. This way, to consider the existence of other dimensions and consequently the influences they may cause, favors an expansion of the perspective, and also brings a detailing about the external factors (organization, society and culture) that influence the dual career couple. To consider that this couple, as well as having personal challenges in the relationship between work and family, is subject to the culture that regulates their roles (men and women) and that directly influences how organizations will handle that topic reveals the merit of this study. This, in turn, draws attention to the organizational sphere and shows that it cannot be detached from this reality. Considering that people management policies, that include dual career couples, are emerging.
\end{abstract}

Keywords: Conceptual model. Dual career. Organization.

Received in 02/23/2000; revised in 06/08/2016; accepted in 08/10/2016; divulgued in 03/01/2017.

*Author for correspondence:

†. Universidade de São Paulo Address: Avenida Pádua Dias, $n^{0} 11$ Piracicaba - SP

Brazil - CEP 13418-900

E-mail: hberlato@usp.br
$\Omega$. Universidade de São Paulo Address: Avenida Pádua Dias, $n^{\circ} 11$ Piracicaba - SP Brazil - CEP 13418-900

E-mail: karen.florentino.correa@usp.br

Note from the Editor: The article was accepted by Bruno Felix. 


\section{INTRODUCTION}

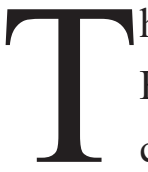

The intention of this work is to continue the research on dual career (SANTOS, 2011) in the Brazilian context. The main purpose is to think over this literature as how the theoretical conceptual model proposed on dual career may explain the relationship between career, family and organization. Couples who live dual career opt for a lifestyle, that in general, has its base on a continuing professional engagement (HARVE; NOVICEVIC; BRELAND, 2009) and their desire for personal growth together (MARTINEZ, 2005). Its definition is, in summary, the union of a man and a woman who together seek to build a family without giving up professional development.

An important fact related to the dual career nomenclature, and that is worth mentioning, is that in Brazil there is not an expression that portrays such a phenomenon yet. Translating the term "dual career", one can refer to the understanding of a single person with two careers, which is common in the country. By studying the international literature, it is possible to notice that the term dual career reflects only and exclusively the career of the couple. In Brazil it does not. There will be future efforts to create a term that can portray this concept in essence. To understand the cultural context is one of the first steps for the birth of such vernacular. Therefore, for this article, the term still in English - dual career has an important role, that is to keep the essence of the concept.

It is also important to highlight that studies on dual career, whether at individual or organizational field, need better understanding, in order to differ from other theories that deal with conflicts arising from the career/family relationship. The choice for continuous career development of both partners produces something impressive in this relationship. Occupations typically require a significant investment in professional qualification and education level of each one of them (BIRD; SCHNURMAN-CROOK, 2005). That is the reason why some authors distinguish couples who live a dual career from other couples. This is because, considering the terminology, the literature shows a wide range of classifications that describe and characterize families in which couples work (DUXBURY et al., 2007; LUCCHINI et al., 2007). It is noteworthy that not all families (in which couples work) practice the dual career.

From the literature on the subject it is possible to note that this conceptual model, focused on the individual, has limitations. This is because the dual career contemplates the double look, in other words, the individual and the organization are essential to fully understand what is conventionally called dual career. Therefore, the main purpose of presenting a readjustment of the theoretical conceptual model (BERLATO, 2015) is to broaden the perspective on dual career and even show how it can contribute to the understanding of the relationships involving career/family and organization. 
Duxbury et al. (2007) emphasize a distinction between dual career couples and dual earner couples (couples with double salary). In the second one, according to the literature, the couples don't express a concern with the development of their careers, but with the financial reward that work provides. These couples also do not care about the way they are hired, nor whether this work will bring any benefit besides the ones related to the income (BRANNEN; CONNELL; MOONEY, 2013; PEDERSEN; KILZER, 2013; MINNOTTE; MINNOTTE; PEDERSEN, 2013 KAUR; KUMAR, 2014 ALLEN; FINKELSTEIN, 2014).

Such consideration becomes relevant in order to support the theoretical concepts involving the discussion of dual career, besides highlighting that researches in this area do not deal only with issues related to family and career, as already mentioned, but show various other aspects among them, like the way spouses face and prioritize their choices. This also allows characterizing the profile of the professional which companies will deal with, in terms of their personnel management practices.

There is also no way of ignoring the subjectivity of individual aspects. Considering that subjectivity is the fundamental unity of human beings, in which this should have the recognition of a unique, singular, reflective and impulsive element (CHANLAT, 1990). This fact creates the need of a more careful look, so the actions that could put the dual career couple in a general format are not in a standard in such a way that is not possible to consider the individuality and subjectivity of each person, since the reflection here is not sustainable in a single individual, but in the couple, conceived and analyzed as a dyad (ROBILA, 2012). The emphasis of this analysis, though with a focus on the organizational area, does not exclude abstract individual characteristics, which makes it more complex and requires an idiosyncratic look.

If in another model the dual career theme was addressed for couples, it is now important to understand, from a theoretical model, the dual career in the perspective of the organization. This is because the policies and organizational practices may have different purposes comparing to the ones of dual career couples. The aim is to establish the need for people management models to be in harmony with the wishes of dual career couples who are part of organizations. If in the 1980s the existence of dual career couples was not so common in Brazil, nowadays organizations increasingly receive these couples, which impacts the need for people management models to keep up with these social changes. As a result, the purpose here is to build a theoretical model of dual career from the perspective of the organization.

The justification for the construction of this theoretical model is that studies on dual career take couples much more into account, marginalizing the role that organizations, their policies and people management practices have (BAGGER; LI, 2014). If there is no harmony between people management models and the aspirations and dilemmas of families today, organizations can lose much of their intellectual source. This lack of harmony between the organization and the individual 
may result in a lower performance of individuals in the context of organizations (KOSSEK; LIRIO; VALCOUR, 2014).

To achieve this purpose, the present essay starts with a contextualization on the emergence of the essence of the term dual career, which according to the literature is a phenomenon. Shortly after this contextualization, the article presents the integrated model from Berlato (2015), and finally the exposure of the new conceptual model and the assumptions that sustain this realignment on the previous proposal takes place.

\section{THE CONTEXT FOR THE ARISING OF THE DUAL CAREER TERM AND CURRENT APPROACHES}

An essential characteristic that breaks the discussion of dual career has its base on the progress of understanding the position of women in modern society (CRAMER et al., 2012; POWELL; GREENHAUS, 2010). The access to the business market and the autonomy in "out of home" actions legitimized the role of this woman, who no longer carries the characteristics of a "home caregiver". This fact was able to shake some rudimentary social structures, especially the defenders of a standard which established males as breadwinners and females as caregivers (MEULDERS et al., 2008). These changes instill questions about the roles and responsibilities of men and women within the family, exposing them even more. It is possible to assert the mutations in the role of women at home, in the labor market and society, from the intense literature on gender (CALAS; SMIRCICH, 2002; HIRATA; SEGNINI, 2007; KANAM, 2010; CRAMER et al., 2012; KASSENBOEHMER; SINNING, 2014).

However, as the dual career concept arises from the 1970s (RAPOPORT; RAPOPORT, 1971) and highlights the implications of a relationship involving marriage (husband and wife) and professional development(HALL; HALL 1980; HUNT; HUNT, 1982), therefore, the understanding of the studies on gender are part of a category of analysis that took place in a short time before that event (SCOTT, 1986). This reveals how the conception of dual career is closely linked to gender, considering that both topics broke out in similar periods, which explains its mention in this context.

Briefly, it is worth mentioning that in the early twenties, it was cultural to accept that gender roles were based on a doctrine that treated them in isolated spheres. According to this ideology, men and women have different natures, and the roles played in society should be radically unequal. Consequently, there was an intense movement of men immersed in the business world and women in domestic activities (KORABIK, 1999). With the restructuring of labor, it was possible to observe a smaller reliance on physical strength, a fact that, for a long time, put man in a position of primacy in relation to woman (COOK, 1985). 
Powell (1990) points out that as the years went by women began to devote more time to paid work and less to education and child care. The change of this scenario reveals a migration of women, from the domestic environment to external (public) work spaces, even if men still rule these spaces and impose on women a representation of a secondary activity. It is also possible to notice that over the last few decades, specifically, there has been a growing achievement by women, in what is known as paid work, especially those that are part of the middle and upper class (ABRAMO, 2007; MEULDERS et al., 2008).

The gradual increase of women in the labor market, especially those with children, is one of the most important social and economic phenomena that happened in recent times, considering the way it interferes and modifies the understanding of structures on gender and employment (MOORE; MOORE, 2011; HAMMER; ZIMMERMAN, 2011).

From these facts, it is easy to perceive that a new scenario is taking place, in which there's not much strangeness in relation to the new role of women and the space they won in society and family. This achievement, besides generating strong changes, promotes the emergence of the dual career, since it allows married women to have initiatives in the work field through the development of their career, along with their partners. It is important to mention that this fact leads to a readjustment of concepts that can cause big impacts on society, and especially on individuals (POWELL, 1990; SCHNEIDER; WAITE, 2005).

At this point is worth presenting the classic definition of dual career, which was born from the urgent need to study the movement in which husband and wife leave home together to work. Dual career families symbolize, concisely, a new type of family structure (RAPOPORT; RAPOPORT, 1976) in the contemporary scenario (DUXBURY et al., 2007), which express the desire of both spouses to develop their careers, as well as maintaining a family (RAPOPORT; RAPOPORT, 1976). It has, as support, several gender and career theories.

The practice of dual career has in its foundation the primacy of the couple in the areas of family and career. The choice for one of these domains, or the option for both simultaneously, characterizes typologies of dual career that define the inclinations of the couple on some of these domains (RAPOPORT; RAPOPORT, 1971; HALL, HALL 1980; HUNT AND HUNT, 1982). These types bring different perceptions in couples, which can be positive (treated in the literature as benefits) and/or negative (conflicts and dilemmas) for the couple. All as a result of the importance that work and family have on people's lives (JANASZ, et al., 2013; CRAIN, et al., 2014).

Recent researches show the importance of the theme nowadays. There is an interest in gathering information about the relationships and associations of married couples on the spheres that involve work and family. The issues that are part of the discussion permeate various aspects that the model brings (SANTOS, 2011). A study with 70 dual career couples deserves a highlight, 
since it was able to present the idea of a significant association between the pressure of work on the part of the organization and the age of the children. The research shows that young parents, whose children are up to two years old, tend to lose quality time with their children and struggle with the management of their time due to the increase of work pressure and stress. From an organizational perspective it is safe to say that this struggle can result in high absenteeism, turnover and less commitment (KAUR; KUMAN, 2014).

Matias and Fortaine (2015) from a study with 100 dual-earner couples, reveal that is possible to associate the use of women's confronting strategies with conflict and enrichment of work and family in a higher level than men's. This fact reinforces the strong presence of pre determined roles to men and women.

Besides that, there is an interest in identifying types of dual career couples, as in the research of Berlato (2015). From a different comprehension of family identity, Masterson and Hoobler (2014) came to four dual career types (non-traditional, family first, outsourced, and egalitarian). Such types result in different combinations of family identities.

Other studies also show that dual career management mainly includes the factors "time" and "teamwork". The time factor is part of a dilemma, as an example: time for family, time for the spouse, time for yourself. But the teamwork can be the answer to this difficulty in sharing the creation of planning and decision making, as having children and knowing each other well (FIDER et al., 2014). Considering this, the work of Sultana, Tabassum and Abdullah (2014) deserves special attention, which identified nine challenges that dual-career couples have to deal with, which are: time for children, conflict home-work, conflict work-family, confidence to external support (like nannies and cleaners), personal welfare, lack of time for family, lack of time for domestic activities and difficulties in maintaining social relationships.

These researches reveal a few of the discussions on an international level and show the amount of issues that still need special attention in Brazil. The subject is ample and presents stuffed edges that need improvement, by bringing more policies and actions to individuals and organizations.

\section{THE INTEGRATED CONCEPTUAL MODEL OF DUAL CAREER}

As a result of this first look, under a national perspective, it's possible to consider the construction of the understanding of what Rapoport and Rapoport (1971) call the dual career phenomenon, which happened with the proposal for an integrated conceptual model of dual career, which, briefly, tried to align the key concepts on the subject in order to explain the variables that are suffer influences from that system.

The model was the result of a research from Santos (2011), as exposed in Figure 1.This model has proposed integrating the main aspects that characterize and influence dual career. Couples who 
choose this lifestyle suffer a direct influence by dimensions treated as individual and collective, at first. Figure 1 shows that the collective dimension includes two aspects - organization and society. The factors related to society involve the definitions of roles between men and women; and regarding the organization, the relationship between dual career couples and business. On the other hand, the individual dimension conceives interpersonal vision that turns back to the perception among people and intrapersonal, that highlight the perception of one itself(WILCOX-MATTHEW; MINNOR, 1989).

It is important to emphasize, on the model of Santos (2011), that the choice between two domains (family and career) are essential to determine which of those influences will have more impact on the dual career type that the couple choose to live. Once there are influencing factors and the prevalence of domains that lead to types of dual career, it is also worth highlighting the consequences of this practice, which can be beneficial, but also bring conflicts and dilemmas to

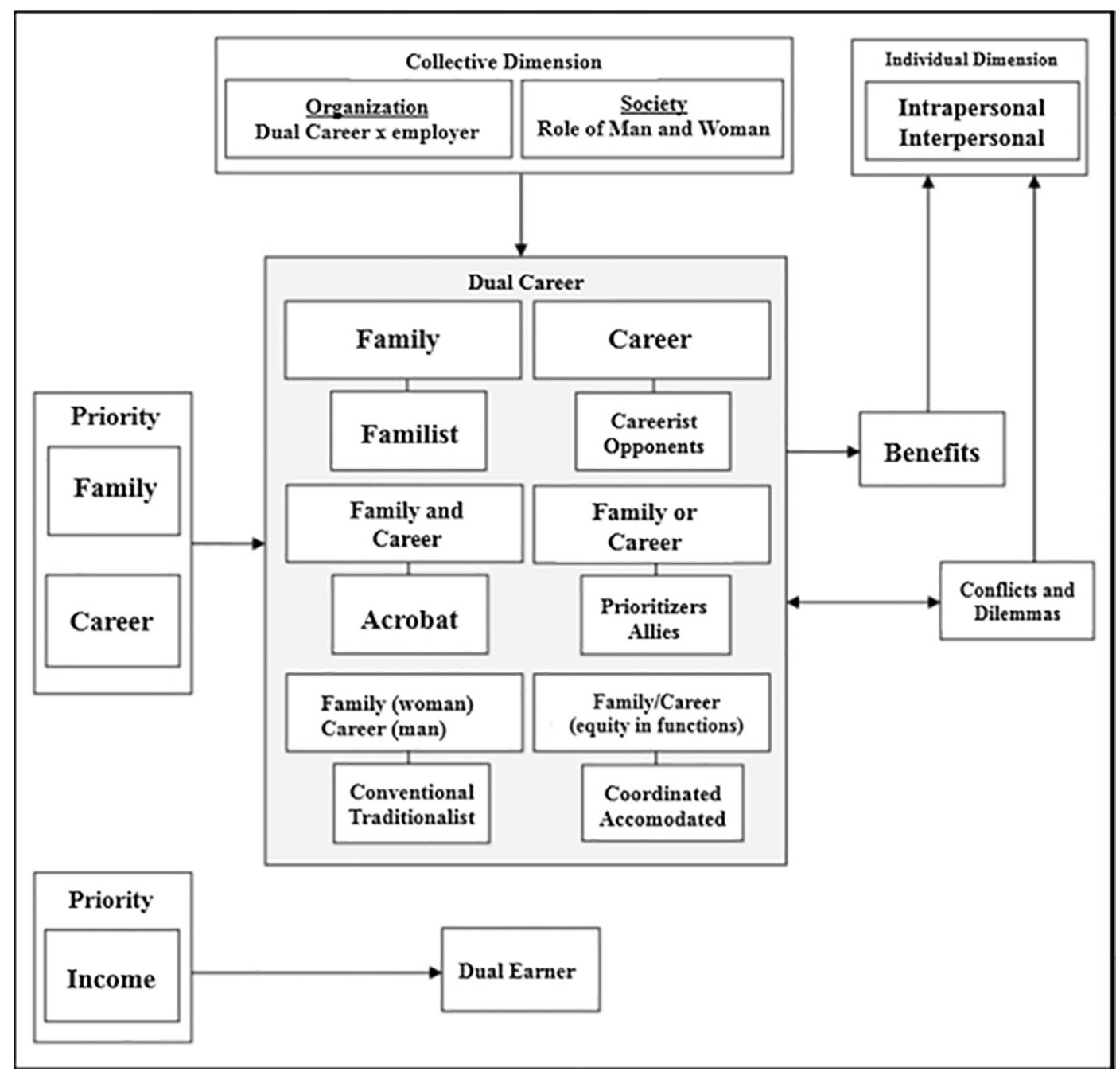

Source: SANTOS (2011, p.86).

Figure 1. Integrated Conceptual Model of Dual Career. 
couples who opt for it. According to the model, both interfere with family relationships (couple and/or children) and on the individual dimension.

The dual career types (SANTOS, 2011), resulting from the choice of domains, has its genesis from a pioneer literature (RAPOPORT, RAPOPORT 1971; HALL, HALL, 1980; HUNT, HUNT, 1982) on the subject and gives subsidies for the displayed nomenclature. From the relevance of the model types, it is necessary to bring a brief explanation of these typologies, linked to the respective authors. Rapoport and Rapoport (1971) describe four types of dual career (familist, careerist, conventional and coordinated). The familist type carries the characteristic of having both partners deeply engaged in the domestic sphere, in other words, they have careers, but the priority is related to home, in case they need to choose. The careerist type classifies couples that invest in their careers. The conventional type represents the traditional family, in which woman plays her role as housewife (activities directed to the family) and man performs his role as provider (activities focused on career). The last type, the coordinated, suggests a careerist husband, willing to cooperate in the domestic sphere, and a family-centered woman, with guidance for career.

Hall and Hall (1980) also identified four types of dual career (accommodated, opponents, allies, and acrobats). The accommodated proposes a pattern in which one partner has high participation in career and small at home, and the other has opposite priorities. Thus, the degree of involvement of each partner complements the other. The opponents, however, characterizes partners who are usually too involved in their careers and do not manifest any involvement with family or any support function to its pair. The allies couples are usually very involved with career or family, but not in all functions (they join forces in a priority). Both partners can have a strong focus on family and less identification with career, or the reverse of that. The last type, acrobats, establishes that the couple is usually very involved in all their roles. For them, the relationship with the family functions is just as important to their careers.

Finally, Hunt and Hunt (1982) present a triple typology of dual career (traditionalists, prioritizers and integrators). The traditionalists represent a conventional home, with divisions of roles and gender: the female is associated with the housework and the man to the provider attribute. Prioritizer couples are the ones who reject the notion of gender and the prescription of the roles. They have the possibility to choose between work and family issues functions. And finally, the integrators have marital and parental roles as well as working roles. They work together in the same professional field and can be colleagues in the same area or owners of their own business.

However, it is essential to point out that the choice between two domains (family and career) is important to determine which of those influences will have more impact on the type that the 
couple chooses. If this occurs, it will bring assertive and conflictive derivations, judging by the fact that both interfere in family relationships and individual dimension.

Greenhaus and Kossek (2014) point out that one of the great incentives couples feel is the balance between family and career demands. This, in turn, closely links these two areas to the dual career context, especially when dealing with couples trying to associate home and career, the genesis of determining dual career types. Therefore, the authors consider family and career in a priority level, with the intention to demonstrate that the choice of one item by the couple will determine the type of dual career that best suits them. Both spheres can be a priority for the couple, which also classifies a type of dual career.

From the conception that the couple has on the relationship between career and family, it is possible to determine various types of dual career (RAPOPORT; RAPOPORT, 1971; HALL; HALL, 1980; HUNT; HUNT, 1982; DUXBURY et al., 2007). In the practice of dual career, most benefits are present in women's life (STROH; REILLY, 1999; LOO; THORPE, 2005; CHANDRA; HINDU, 2010), which promotes the adhesion of the number of couples who take upon themselves this lifestyle (GILBERT, 1985; KIDWELL; KIDWELL, 2006). Yet the relationship between home and career still causes issues, which culminate in situations of ambiguity and conflict, leading to an adverse shock to the couple's relationship. Conflict situations between partners can change their priorities, causing the change of a dual career type to another (HALL; HALL, 1980).

In a horizontal perspective of the model, it appears that once the priorities are set (family and career), it is possible to define types of dual career. What in turn, can bring benefits as well as conflicts and dilemmas, which, according to its intensity can influence some priorities, causing the alternation of the dual career type.

Considering the benefits and conflicts in the vertical level, the individual dimension (WILCOX-MATTHEW; MINOR, 1989) suffers the impact of both aspects (positive and negative), in other words, the interpersonal field (family relations), and the intrapersonal field (individual) experience impacts in positive and negative ways by dual career types. On the other hand, even in the vertical level, the so-called collective dimension, which includes the sub-dimensions society and organization (WILCOX-MATTHEW; MINNOR, 1989), presents factors that influence the classification of dual career types. In this dimension, the way society determines the social roles of men and women (JACOBS, 1999) and also the way that organizations deal with the relations between career and family with its employees interfere in an incisive way on the lives of dual career couples. 
The presentation of variable that prioritizes the income in the model has the purpose of characterizing dual earner couples. These couples prioritize exclusively the financial issue, and ignore their career development.

From the specific objectives of the research (BERLATO, 2015), that focus exploring individual aspects of dual career couples, it reached a meaningful final model (Figure 2). This model started from career and family priorities, and did not consider the collective dimension, and also, included the analysis of gender to the factor.

Thus, the final model allowed, as already said, from two main variables - career and family - to infer that, from thinking about them as separate items or in combination with other variables, it is possible to characterize some types of dual career (RAPOPORT; RAPOPORT, 1971; HALL; HALL, 1980). This model also considered that the gender variable would also influence on the classification of other types of dual careers, and that, for each type, there are situations that reflect benefits/conflicts/dilemmas. To understand the perception of the couple (man and woman) on their roles in each domain was important to target the type of dual career that fits this couple. That's

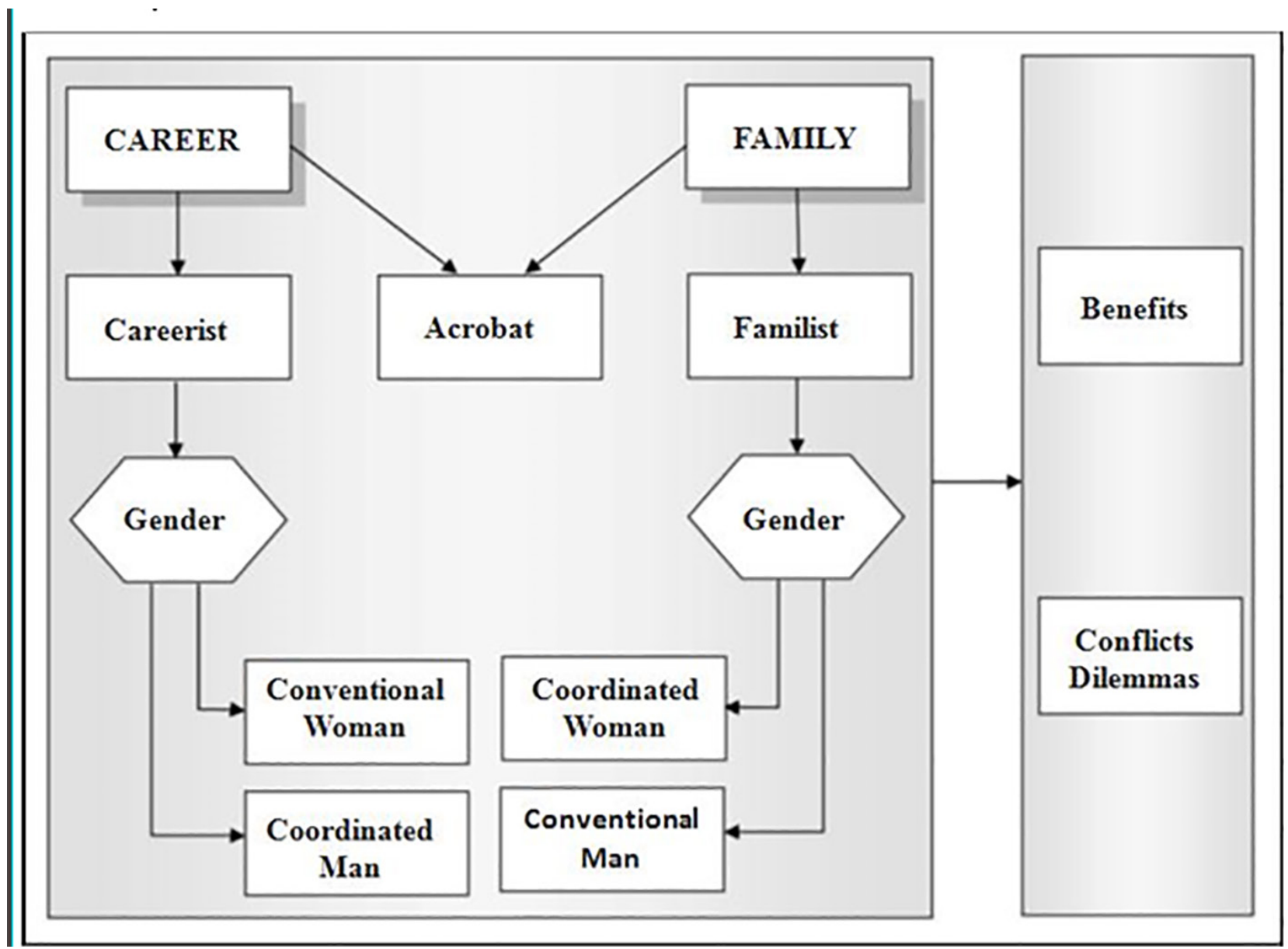

Source: BERLATO (2015, p.517).

Figure 2. Explanatory final model 
because the characterization of some types from the gender is crucial, considering the focus that it gives to the role of man and woman.

\section{ADAPTATION OF THE CONCEPTUAL DUAL CAREER MODEL: INTEGRATING INDIVIDUALS, ORGANIZATIONS AND CULTURE}

This research (SANTOS, 2011) made significant contributions to human management studies, in particular to the career area, first by dealing with a theme never studied before in the Brazilian scenario, and second by exploring the dual career phenomenon in Brazil, identifying factors associated with it. However, it still left a vast field for future researches, including the collective dimension, a situation that raised the motivation for a closer look about the theme.

It was appropriate to rescue the conceptual and the explanatory model applied in previous research in order to contextualize the new steps that the paper in question will address. And also to present specific adjustments to the model, considering the results from the study. For example, the collective dimension of the model of Santos (2011) did not ponder the impact of the culture variable in Brazilian dual careers, which, though not mentioned, strongly influences the collective dimension (LEGOHEREL, et al., 2009; CASPER, et al., 2011). Cultural factors could justify the research findings which revealed that dual career couples perceive more benefits than conflicts in their relationship. The international literature is against this result, since conflicts are much more compelling than benefits (MAKELA; KANSALA; SUUTARI, 2011; BHOWON, 2013; SHIMAZU, et al., 2013; STEENBERGEN; KLUWER, 2014; RODRIGUEZ-MUÑOZ; NIELSEN, 2014). Cultural factors also influence the social dimension (WILCOX-MATTHEW; MINNOR, 1989), this is because, historically, relations of patriarchal gender are prevalent in the Brazilian society and the symbolic constructions and cultural elaborations are very strong in hierarchical social practices. Therefore, for a long time, society understood that male overlaps the female. This fact results in a condition of privilege and power to men, leading women to a subordination that, in turn, reflects in labor relations, production and reproduction based on the distinction between genders (MATOS, 2009).

That said, looking back on dual career theories, considering the initial results in the Brazilian context, to better understand and also explain it, it becomes vital to readjust the model from Santos (2011), and consider three dimensions for analysis of the study. The socio-cultural dimension, the individual dimension and the organizational dimension.

The proposal of building a conceptual model arose from the attempt to integrate the main aspects that characterize and influence the dual career phenomenon. From the purpose of this study that continued previous research, it was appropriate to accomplish a readjustment, since the focus has changed, leaving the individual field and focusing on the organizational field. 
Considering that the studies about career, especially the ones that focus on dual career, demonstrate its close ties to the discussions on gender, it is clear that the dual career practice among couples is a subject full of characteristics that strongly influence it (STEENBERGEN; KLUWER, 2014). Cultural and historical aspects also influence different variables.

Therefore, and based on what was discussed earlier, the readjustment of the model works, at first, to highlight the existence of three major dimensions influencing and influenced in the understanding of dual career: socio-cultural dimension; individual dimension and organizational dimension.

The first dimension, the socio-cultural dimension, assigns the character of an influential dimension, considering that gender, power relations and the symbolic aspects are imbued with a legitimated historical in society. This dimension affects the other two dimensions. Thus, the dual career is a representation of what this dimension has built over time in relations between men and women, the task and responsibilities divisions and forms of authority.

The second dimension, the individual dimension, is directly related to couples who live dual career. They suffer influences from the socio-cultural dimension and also the organizational dimension. The study by Santos (2011) reached the perspective of the individual that points out that these two spheres (family and career) have a direct connection to the dual career context, which has the characteristics of having couples who seek to combine family with career, another starting point for the definition of the types of dual career. Note that both spheres can be priorities for the couple, which can also be a type of dual career.

A major challenge that couples often feel is the balance of the demands of family life and career. There is a theoretical perspective that highlights the multiple roles that an individual develops. However, this function can result in role difficulties that individuals experience when seeking to perform successfully all the demands (family and career), which are often conflicting with each other (GREENHAUS et al., 2011). Thus, the individual dimension influences the organizational because there are interpositions between these two dimensions.

The organizational dimension brings the perspective of the organization on dual career. It is important to consider that the dual career is influential and influenced by organizational dimension. However, the organization ends up influencing more individuals, since two important things come from it: income and work development (POWELL; GREENHAUS, 2012). The organizational dimension, which suffers influences from the socio-cultural dimension, has management practices that may or may not influence dual career. Management practices include what Gilmore and Fannin (1982) refer to as traditional practices and new practices. Traditional practices are those generally in use, in other words, applied to all the members of the organization. The new practices involving career development and more specific actions are special for dual career couples. 
The traditional and new practices that can impact dual career couples involve several policies. In traditional practices, the recruitment policy concerns rewards and incentives for the person. In nepotism nobody can control a family member. The transference policy offers to the employee things actually normally happen. The scheduling is the standard format to meet the company's needs. And finally, the basis for the training and development are the management of the development of the company. From the same policies, some new practices take place. In recruitment, the use of a practice of locating positions is common, as well as other aspects according to the perspective of the spouses. In nepotism there is the expectation that a family member supervise the other. In the transference policy, the transference of both proceeds and transitional licenses extends. The schedule, in this case, allows flexibility to meet the demands of the couple and the company. Finally, in training and development, special guidance has its focus towards dual career couples.

Expanding the range it's possible to notice that the dual career in the individual dimension provides benefits to the organization, providing conditions for the organization to know what practices to use. That is precisely one of the main purposes of this study. To know the other side of the model in order to know how the information from the organizational side, in addition to the individual side, contributes to understanding the dual career in both dimensions. It's important to emphasize that both dimensions, although distinct from each other, share something similar: the individual. However, the seizure of the organizational dimension on the individual causes a huge impact on the perspective that it has on the home/work relationship (POWELL; GREENHAUS, 2012) and professional vision of success. Thus, adding the duality (husband and wife), that is imperative in dual career, to the organizational dimension, that has the main characteristics in the manager's figure and its main actions (BAGGER; LI, 2014), it takes an extreme importance when the model assimilates it to the individual dimension (GREENHAUS; KOSSEK, 2014).

The conceptual model (Figure 3) seeks to group the main aspects that the literature covers on the dual career theme in order to facilitate all the visibility and focus the concepts of greater interest considering the purpose of this study. Thus, it is possible to verify that the prominence of this new proposal aims, in general, to understand that three dimensions (socio-cultural, organizational and individual) need a more specific consideration and detailing, in order to map more effectively the construction of a wider understanding of the dual career in the Brazilian context.

One of the main changes that the new model exposes gives a greater importance to the sociocultural dimension. This is because several concepts that border dual career suffer large influence of aspects that have historical heritages that in current times are still present among us, whether in organization, family or in the individual's role (GREENHAUS; KOSSEK, 2014). The individual dimension, in turn, not very expressive in the national scenario, from some previous research efforts (SANTOS, 2011), reinforces themes that focus on career and family, considering gender, 
conflicts, but also bringing benefits to these couples. The organizational dimension can enhance because it understands that the dual career requires more specific actions. When considering that it (organization) influences the individual dimension and suffers influences from it, it is clear that its impact is larger and reinforced by the dotted arrow. When management practices focus on dual career, they require two excluding pathways (traditional practices and new practices), which requires organizations to have a closer look on what policies follow or adopt. This encourages the understanding that specific practices deserve attention and what kind of concerns could arise from organizations with this adherence (KOSSEK; LIRIO; VALCOUR, 2014).

Finally, the model reconstruction favors the expansion of the perspective on the whole idea of dual career, aiming to detail external factors (organization, society and culture) that influence the

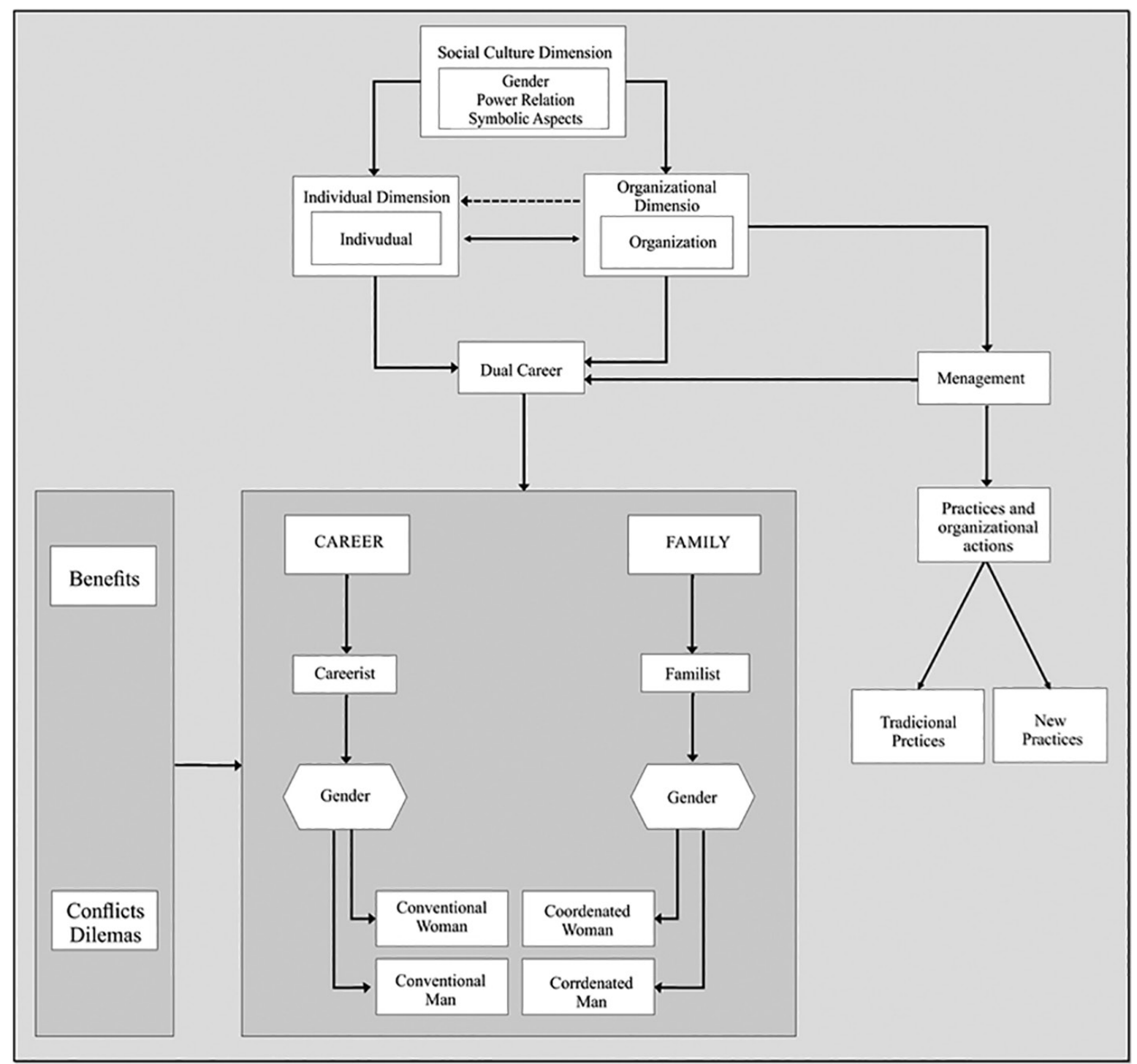

Source: elaborated by the author

Figure 3. Adaptation of the conceptual dual career model. 
dual career couple. The intention of this paper is to contribute to the development of studies on this topic guiding possible paths and research interests.

\section{FINAL CONSIDERATIONS}

The intention of this theoretical essay was to propose the adaptation of the conceptual model on dual career in order to explain, with extra care and details, possible aspects that can influence the construction of the understanding on dual career. Some considerations outlined reflect attention to aspects linked to the gender issue, power relations and symbolism that influence in the construction of relationships between couples. These considerations have a meaning and they are important because it directly affects the social constructions that will condition the directions and decisions not only of dual career couples, but for a society that still determines roles and for a prescriptive organization.

It is worth mentioning that the understanding on the concept of gender, was not formed as an isolated incident, but is the result of a hike in decades that have made history on the conquest of women space into the business market, especially with the career development possibility. Such discussion about dual career can only happen due to this fact, which has been trying to put woman in an "equal" condition to man, allowing, in the individual sphere, that both make your personal and professional choices.

Thus, by considering the organizational space on this discussion, it is acceptable that the understanding regarding the dual career should attract the attention of people management. It is clear that the existence of matters involving personal conflicts can reflect in the professional field, for couples who opt for dual career, which in turn ends up requiring more flexibility from the organization to understand and deal with the various implications arising from this new form of structure. Also, to understand that there may be a need for a change on the structure of society, considering these issues and the way they can impact and interfere in the development and maintenance of policies and organizational practices.

Finally, it is safe to say that old models are reconfiguring, and consequently requiring "readjustments" to these reconfigurations, that means that a pondered look about the new arrangement became a requirement, because as well as models rearrange the molds must also adapt.

It is still interesting to point out that according to the purpose of this essay, in a theoretical way and through a conceptual model of analysis, situations involving the relation between family and careers from the point of view of married people got the attention. Some questions were not addressed because of the focus of discussion. This, in turn, can create limitations; however, further discussion could leave the suggested scope. An empirical research becomes the main way for validation of the model, particularly in a broader perspective. 


\subsection{Practical implications}

The model allows, in a practical way, guidelines from two perspectives; couples and organizations. For couples who opt for the dual-career lifestyle, it is best to have a consensus between husband and wife on the performance of their roles and functions, both in the family domain and at work. The cohesion between the couple will enable them to have satisfaction and still develop their activities, minimizing conflicts that may interfere with and harm those areas.

For organizations, the suggestion is to take a closer look to their employees who practice dual career. Considering that this lifestyle has been increasing significantly, it will probably be impossible that there are no individuals in organizations that are part of this group. The suggestion is that it seeks to deeper knowledge of the employees, in order keep talents, and using the best way to combine professional desires with personal aspirations.

Moreover, people management policies should align in order to propitiate favorable situations to those employees, considering what is essential to their personal life, since personal aspects unobserved by the organization may lead to decrease a high potential person's productivity and also their loss. A major challenge for organizations is to find out the best way to allocate the demands of these employees, considering the intangible aspects that involve the dual career situation, and, from that, to direct practices with more focus on every need.

\subsection{Future Researches}

In view of the novelty of the dual career theme in the field of research in Brazil, it is possible to recognize that a conceptual model of analysis may indicate possible action paths to consider the features that it includes. Thus, some suggestions for future studies could contribute to the alignment of more focused organizational practices and broader view of traditional social concepts and rooted in our national culture.

Thus, the suggestion is to conduct new studies in order to establish a more detailed comparison between genders, since that is an important variable that deserves attention, because based on the impact of these studies on dual career, and investigating how men and women see themselves in a dual career relationship, could favor the identification of the major concerns of each gender on family and career. The literature recommends a single look at the couple, having man and woman as one; however, it is necessary to note that in the national context, men and women are at the mercy of various economic, social, and especially cultural influences, which directly impact the life of each one of them, which encourages a closer look at each gender specifically.

Another suggestion would be to conduct a study that focuses on homosexual couples, considering new family configurations, since this study verified the practice of dual career only in an heterosexual perspective, as it used as a theoretical basis the genesis of the dual career concept, 
which deals at first, with the demands of men and women (traditional couples). Same-sex couples may or may not have different characteristics from these couples.

\section{REFERENCES}

ABELE, A.; VOLMER, J. Dual-Career Couples: Specific Challenges for Work-Life Integration. In: Creating Balance? International Perspectives on the Work-Life Integration of Professionals. KAISER, S.; RINGLSTETTER M. J.; EIKHOF; DORIS R.; CUNHA, M. P. Editors, SpringerVerlag Berlin Heidelberg, 2011.

ABRAMO, L. Inserção das mulheres no mercado de trabalho na América Latina: uma força de trabalho secundária? In: Organização, trabalho e gênero. HIRATA, H.; SEGNINI, L. (orgs), São Paulo: Ed. Senac, 2007.

ALLEN, T.D.; FINKELSTEIN, L.M. Work-Family Conflict Among Members of Full-Time DualEarner Couples: An Examination of Family Life Stage, Gender, and Age. Journal of Occupational Health, v.19, n.3, 2014.

BAGGER, J., REB, J.; LI, A. Anticipated regret in time-based work-family conflict. Journal of Managerial Psychology, v. 29(3), p. 304-320, 2014.

BAGGER, J.; LI, A. How Does Supervisory Family Support Influence Empoyee's Attitudes and Behaviors? A Social Exchange Perspective. Journal Of Management, v.40, n.4, p.1123-1150, 2014.

BARNETT, R. C.; HYDE, J. S. Women, men, work, and family. An expansionist theory. American Psychologist, v. 56, p.781-796, 2001.

BEAUREGARD, A. Corporate Work-Life Balance Initiatives: Use and Effectiveness. In: Creating Balance? International Perspectives on the Work-Life Integration of Professionals.

BERLATO, H.The dual career process in the Brazilian perspective: Unraveling typologies. Revista de Administração, v. 50, n. 4, p. 507-522, 2015.

BHOWON, U. Role Salience, Work-family conflict and satisfaction of dual-earner couples. Journal of Business Studies Quarterly, v.5, n.2, 2013.

BIRD, G. W.; SCHNURMAN-CROOK, A. Professional identity and coping behaviors in dualcareer couples. Family Relations, v. 54, p. 145-160, 2005.

BRADBURY, S. Dual-career couples in R and D labs. Research and Technology Management, v. 37, p.45-47, 1994.

BRANNEN, J.; O'CONNELL, R.; MOONEY, A. Families, meals and synchronicity: eating together in British dual earner families. Community, Work \& Family, London, v.16, n.4, 2013.

BRUCK, C.S.; ALLEN, T.D.; SPECTOR, P.E. The Relation between Work-Family Conflict and Job Satisfaction: A Finer-Grained Analysis. Journal of Vocational Behavior, v.60, p.336-353, 2002.

BRUSCHINI, M. C. A. Mulher, casa e família. Cotidiano nas camadas médias paulistanas. São Paulo: Fundação Carlos Chagas, 1990. 
CALÁS, M. B.; SMIRCICH, L. Do ponto de vista da mulher: abordagens feministas em estudos organizacionais. In: CLEGG, S. R.; HARDY, C. et al. (Ed.). Handbook de Estudos Organizacionais. São Paulo: Atlas, 1999.

CASPER, W.J.; HARRIS, C.; TAYLOR-BIANCO, A.; WAYNE, J.H. Work-family conflict, perceived supervisor support and organizational commitment among Brazilian professionals. Journal of Vocational Behavior, v.79, 2011.

CHANDRA, V. Women and Work-Family interface: Indian Context. Journal of Asia Pacific Studies, v.1, n.2, p.235-258, 2010.

CHANLAT. J.F. Ver une anthropologie de l'organisation. In. Líndividu dansl'organisation, les dimensions oubliées. Quebec: Eska/Laval, 1990.

COOK, E. P. Psychological androgyny. New York: Pergamon, 1985.

COSTA, A.; SORI, B.; BRUSCHINI, C.; HIRATA, H. Mercado de Trabalho e Gênero: Comparações Internacionais. Editora FGV, 420 p. Rio de Janeiro, 2008.

CRAIN, T.L.; HAMMER, L.B.; BODNER, T.; KOSSEK, E.E.; MOEN, P.; LILIENTHAL, R.; BUXTON, O.M. Work-Family Conflict, Family-Supportive Supervisor Behaviors (FSSB), and Sleep Outcomes. Journal of Occupational Health Psychology, v.19, n.2, p.155-167, 2014.

CRAMER, L; CAPPELlE, M. C. A; ANDRADE, A. L. S; BRITO, M. J. Representações Femininas da Ação Empreendedora: Uma Análise da Trajetória das Mulheres no Mundo dos Negócios. Revista de Empreendedorismo e Gestão de Pequenas Empresas, v.1, n.1, jan - abr 2012.

DELAURO, R.L. Successes and Further Goals for Women in the Workforce. Human Rights, v.37, n.3, 2010.

DEMEROUTI, E. The Spillover and Crossover of Resources Among Partners: The Role of WorkSelf and Family-Self Facilitation. Journal of Occupational Health Psychology, v.17, n.2, p.184$195,2012$.

DREW, E.; HUMBERT, A.L. Men have careers, women have babies: unequal parental care among Irish entrepreneurs. Community, Work \& Family, v. 15, n.1, 2012.

DUNPHY, D.; STACE, D. Under New Management. Sydney: McGraw-Hill, 1992.

DUXBURY, L.; LYONS, S.; HIGGINS, C. Dual-Income Families in the New Millenium: Reconceptualizing Family Type. Advances in Developing Human Resources, v. 9, nº 4, p. 472486, 2007.

FRONE, M.R.; RUSSEL, M.; COOPER, M.L. Prevalence of work-family conflict: Are work and family boundaries asymmetrically permeable? Paper presented at the annual conference of the Society for Industrial and Organizational Psychology, Montreal, Quebec, Canada, 1992.

GILBERT, L. A.; RACHLIN, V. Mental health and psychological functioning of dual-career families. The Counseling Psychologist, v. 15(1), p. 7-49, 1987.

GILBERT, L.A. Men in dual-career families: Current realities and future prospects. Hillsdale, NJ: Erlbaum, 1985.

GLAUBER, R. Women's Work and Working Conditions: Are Mothers Compensated for Lost Wages? Work and Occupations, v.39. n.2, 2012. 
GREENHAUS, J.H.; KOSSEK, E.E. The temporary career: A Work-Home Perspective. Annual Review of Organizational Psychology and Organizational Behavior, v.1, 2014.

HALL, D.T.; HALL, F.S. Stress and the two-career couple. In: Current concerns in occupational stress. COOPER, C.L.; PAYNE,R. (eds), New York, 1980.

HAMMER, L.B.; ZIMMERMAN, K.L. Quality of work life. APA handbook of industrial and organizational psychology, Washington, p. 399-431, 2011.

HARVEY, MG.; NOVICEVIC, M.M.; BRELAND, J.W. Global dual-career exploration and the role of hope and curiosity during the process. Journal of Managerial Psychology, v.2, p.178197, 2009.

HEGEWISCH, A.; GORNICK, J.C.The Impact of Work-Family Policies on Women'sEmployment: A Review of Research from OECD Countries. Community, Work \& Family, v.14, p. 119-138, 2011.

HIRATA, H.; KERGOAT, D. A divisão sexual do trabalho revisitada. In: As novas fronteiras da desigualdade: homens e mulheres no mercado de trabalho. MARUANI, M.; HIRATA, H. (orgs), RAPKIEVICZ, C. (tradutora), São Paulo: Senac, 2003.

HIRATA, H.; SEGNINI, L. Organização, trabalho e gênero. São Paulo: Senac, 2007.

HUNT, J.G.; HUNT, L.L. Dual career families: Vanguard of the future or residue of the past? In: Two paychecs: Life in dual-earner families. ALDOUS, J. (ed), p. 41-60, Beverly Hills: Sage Publications, 1982.

JACOBS, J. A. The Sex Segregation of Occupations: Prospects for the $21^{\text {st }}$ Century. In: Handbook of Gender and Work, POWELL, G. (ed.), Sage Publications, 1999.

JANASZ, S.; BEHSON, S.J.; JONSEN, K.; LANKAU, M.J. Dual sources of support for dual roles: how mentoring and work-family culture influence work-family conflict and job attitudes. The International Journal of Human Resource Management, v.24, 2013.

JAYAPRAKASH, M.G.; MADHAVI, Dr.C. Impact of work family conflict on job satisfaction among employees in a public sector organization. Asia Pacific Journal of Research, v.1, n.11, 2014.

KAISER, S.; RINGLSTETTER M. J.; EIKHOF; DORIS R.; CUNHA, M. P. Editors, SpringerVerlag Berlin Heidelberg, 2011.

KANAN, L.A. Poder e Liderança de Mulheres nas Organizações de Trabalho. Organização \& Sociedade, v.17, n.53, 2010.

KASSENBOEHMER, S.C.; SINNING, M.G. Distributional Changes in the Gender Wage Gap. ILRReview, v.67, n.2, 2014.

KAUR, G.; KUMAR, R. Organizational work pressure rings a "time-out" alarm for children: A dual-career couple's study. Asian Journal Of Management Research, v.4, n.3, p.583-596, 2014.

KAWAKAMI, N. Work-to-family Conflict and Family-to-work Conflict among Japanese Dualearner Couples with Preschool Children: A Spillover-Crossover Perspective. Journal of Occupational Health Psychology, v. 55, 2013.

KIDWELL, L.A.; KIDWELL, R.E. Louise and Sidney Homer: a $21^{\text {st }}$ century dual-career couple, circa 1911. Journal of Management History, v.12, 2006. 
KIMMEL, A.; ARONSON, A. Men \& Masculinities: A Social, Cultural, and Historical Encyclopedia. 2004.

KORABIK, K. Sex and Gender in the Millenium. In: Handbook of Gender and Work, POWELL, G.N., Sage Publications, London, 1999.

KOSSEK, E. E., VALCOUR, M., LIRIO, P. The Sustainable Workforce: Organizational Strategies for Promoting Work-Life Balance and Well-Being. In: Work and Wellbeing. COOPER; CHEN,P. (eds.), Oxford, UK: Wiley-Blackwell, 2014.

LAURING, J.; SELMER, J. The supportive expatriate partner: An ethnographic study of partner involvement in expatriate careers. International Business Review, v. 19, p. 59-69, 2010.

LEGOHEREL, P.; DAUCE, B.;HSU, C.; RANCHHOLD, A. Culture, time orientation, and exploratory buying behavior. Journal of International Consumer Marketing, v.21, p.93-107, 2009.

LOO, R.; THORPE, K. Relationships between attitudes toward women's roles in society, and work and life values. The Social Science Journal, v.42, p. 367-374, 2005.

LUCCHINI, M., SARACENO, C., SCHIZZEROTTO, A. Dual-earner and dual-career couples in contemporary Italy. Zeitschrift für Familienforschung, 19. Jahrh., Heft 3/, p. 290-310, 2007.

MAKELA, L.; KANSALA, M.; SUUTARI, V. The roles of expatriates' spouses among dual career couples. Cross Cultural Management: An International Journal, v. 18, n. 2, p.185-197, 2011.

Mäkelä, L.; SUUTARI, V. Work-life interface of self-initiated expatriates: Conflicts and enrichment. In Managing talent of self-initiated expatriates: A neglected source of the global talent flow, VAIMAN, V.; HALSBERGER,A., p. 278-303, 2013.

MARCONI, M.; LAKATOS, E.M. Fundamentos de Metodologia Científica. 7. ed. São Paulo: Atlas, 2007.

MARTINEZ, S. Women's intrinsic and extrinsic motivations for working. Being Together, Working Apart: Dual-Career Families and the Work-Life Balance. New York: Cambridge University Press, 2005.

MARUANI, M.; HIRATA, H. As novas fronteiras da desigualdade: Homens e mulheres no mercado de trabalho. São Paulo: Senac, 2003.

MASTERSON C. R. AND HOOBLER J. M. Care and career: A family identity-based typology of dual-earner couples. Journal of Organizacional Behavior, 36, pages 75-93, 2014.

MATIAS, M. \& FONTAINE, A. M. Coping with work and family: How do dual-earners interact? Scandinavian Journal of Psychology, 56, 212-222, 2015.

MATOS, V. C. S. Um Estudo Histórico das Relações de Gênero e Classe. Revista Multidisciplinar da UNIFESP, Saber Acadêmico, n.7, 2009.

MEULDERS, D.; PLASMAN, R.; DE HENAU, J.; MARON, L.; DORCHAY, S. Trabalho e Maternidade na Europa. Condições de trabalho e políticas públicas. In: Mercado de Trabalho e Gênero: Comparações Internacionais. COSTA, A.; SORI, B.; BRUSCHINI, C.; HIRATA, H. (orgs), Rio de Janeiro: FGV, 2008.

MINNOTTE, K.L.; MINNOTTE,M.C.;PEDERSEN,D.E. Marital Satisfaction among Dual-Earner Couples: Gender Ideologies and Family-to-Work Conflict. Family Relations, v.62, n.4, 2013. 
MOORE, D.P.; MOORE, J.L.; MOORE, J.W. How Women Enterpreuners Lead and Why They Manage That Way, Gender in Management: An International Journal, v.26, p. 220-233, 2011.

NEWGREN, K.E.; KELLOG, C.E.; GARDNER, W. Corporate Responses to Dual Career Couples: A Decade of Transformation. Akron Business and Economic Review, v.19, p.85-96, 1988.

PEDERSEN, D.; KILZER, G. Work-to-Family Conflict and the Maternal Gatekeeping of DualEarner Mothers with Young Children. Journal of Family and Economics Issues, v.35, n.2, 2013.

PIERCE, J.; DELAHAYE, B.L. Human Resource Management Implications of Dual- Career Couples. The International Journal of Human Resource Management, v. 4(7), p. 905-921, 1996.

POWELL, G.N. One more time: Do female and male managers differ? Academy of management executives, v.4, p.68-75, 1990.

POWELL, G.N.; GREENHAUS, J.F. Sex, Gender, and Decisions at the Family $\rightarrow$ Work Interface. Journal of Management, v.36, 2010.

RAPOPORT, R.; RAPOPORT, R.N. Dual-Career Families Re-examined. New Integrations of Work and Family. New York: Harper \& Row, 1976

RAPOPORT, R.; RAPOPORT, R.N. Dual-career families. First edition published by Harmonds worth. London, England: Penguin Books, 1971.

REED, C. M.; BRUCE, W. M. Dual-Career Couples in the Public Sector: A Survey of Personnel Policies and Practices. Public Personnel Management, v. 22(2), p. 187-99, 1993.

ROBILA, M. Family Policies in Eastern Europe: A Focus on Parental Leave. Journal of Child and Family Studies, v.21, n.1, p.32-41, 2012.

ROSIN, H.M.; KORABIK, K.; MCELWAIN, A.K. An examination of gender differences in workfamily conflict. Canadian Journal of Behavioural Science, v.37, p.283-298, 2005.

SANTOS, H.B. O processo de dual career family: um estudo sobre os impactos e implicações na vida do casal. 2011. 272p. Tese (Doutorado em Administração) - Faculdade de Administração, Economia e Contabilidade, Universidade de São Paulo, São Paulo, 2011.

SANZ-VERGEL, A.I.; RODRÍGUEZ-MUÑOZ, A.; NIELSEN,K. The thin line between work and home: the spillover and crossover of daily conflicts. Journal of Occupational and Organizational Psychology, v.88, 2014.

SEND. E. Marital Satisfaction among Dual-Earner Couples: Gender Ideologies and Family-toWork Conflict. Family Relations, v.62, n.4, 2013.

SCHNEIDER, B.; WAITE, L. J. Being Together, Working Apart: Dual-Career Families and the Work-Life Balance. Cambridge: Cambridge University Press, 2005.

SCHULER, R.S.; MACMILLAN, I. C. Gaining Competitive Advantage Through Human Resource Management Practices. Human Resource Management, v.23(3), p. 241-55, 1984.

SCOTT, J.W. Gender: A Useful Category of Historical Analysis. The American Historical Review, v.91, n.5, 1986.

SEKARAN, U. Dual-Career Families: Contemporary Organizational and Counselling Issues. Jossey-Bass, San Francisco: 1986. 
SHIMAZU, A.; BAKKER, A.; DEMEROUTI, E.; SHIMADA, K.; KAWAKAMI, N. Workaholism and well-being among Japanese dual-earner couples: A spillover-crossover perspective. Social Science \& Medicine, v.73, 2011.

SHIMAZU, A.; KUBOTA, K.; BAKKER, A.; DEMEROUTI, E.; SHIMADA, K.; SILVA, M.T.T. De; PRIYASHANTHA. Changing gender stereotypes: the impacto $\mathrm{f}$ conflicts in dual career families on turnover intention (with special reference to female professional in Sri Lanka). International Journal of Arts and Commerce, v.3, n.5, p.1-14, 2014.

STEENBERGEN, E.F.; KLUWER, E.S. Work-Family Enrichment, Work-Family Conflict, and Marital Satisfaction: A Dyadic Analysis. Journal of Occupational Health Psychology, v.19, n.2, p. 182-194, 2014.

STROH, L.; REILlY, A. Gender and Careers: Present Experiences and Emerging Trends. In: Handbook of Gender and Work, POWELL, G. (ed.) Sage Publications, 1999.

SUlTANA, N.; TABASSUM, A.; ABDULlAH, A. M. Dual-Career Couples in Bangladesh. Exploring the Challenges. Canadian Journal of Family and Youth, 6(1), p. 29-57, 2014.

THEUNISSEN, B.; VUUREN, L.V.; VISSER, D. Communication of job-related information and work-family conflict in dual career couples. Journal of Industrial Psychology, v.29, p.18-25, 2003

WET, W.; VAN ZITTERT, P.; KOEKMOER, E.; TREURNICH, E. Differences in the wellbeing of dual-earner parentes with young children. South African Review of Sociology, South Africa, v.43, n.3, p.106-128, 2012.

WILCOX-MATTHEW, L.; MINNOR, C.W. The dual career couple: Concerns, benefits, and counseling implications. Journal of Counseling \& Development, v. 68, 1989. 